Nursing News: Jurnal Ilmiah Keperawatan Vol 5, No 2, Tahun 2021 ,hal 56-62

Tersedia online di https://publikasi.unitri.ac.id/index.php/fikes

ISSN 2527-9823(online)

\title{
Pengetahuan Mahasiswa Tentang Penggunaan Alat Pemadam Api Ringan (APAR) Berhubungan Dengan Sikap Dalam Penanggulangan Kebakaran
}

\author{
Ani Sutriningsih ${ }^{1)}$, Rachmat Chusnul Choeron ${ }^{2)}$, Stefani A. Ndae ${ }^{3)}$ \\ ${ }^{1,2,3)}$ Program Studi Pendidikan Profesi Ners, Fakultas Ilmu Kesehatan, \\ Universitas Tribhuwana Tunggadewi Malang \\ Email: pepinndae22@gmail.com
}

\begin{abstract}
Fires can be prevented but the incidence is still quite high so it is important to know how to deal with them, especially in the use of light fire extinguishers (APAR). A fire incident requires a quick response to fire. The purpose of the study was to determine the relationship between students' knowledge about the use of a Light Fire Extinguisher (APAR) with fire prevention attitudes in the Chemistry Laboratory of Unitri Malang. The research design used cross sectional. The sample consisted of students of Chemical Engineering UNITRI Malang in the class of 2019 as many as 53 respondents who were taken using simple random sampling. Collecting data using questionnaires and analyzed by fisher-exact test. The results obtained that respondents have a good level of knowledge category (58.5\%) and have a good attitude category (67.9\%). Fisher-exact test analysis found that there was a relationship between students' knowledge about the use of fire extinguishers and attitudes in fire prevention. It is hoped that there will be training on the use of fire extinguishers on an ongoing basis and continuous socialization will be carried out after the training so that they can know how to deal with fires.
\end{abstract}

Keywords: attitudes; fire; fire extinguishers; knowledge

\begin{abstract}
ABSTRAK
Kebakaran dapat di cegah tetapi kejadiannya masih cukup tinggi sehingga penting pengetahuan dalam penanggulangannya terutama dalam penggunaan alat pemadam api ringan (APAR). Kejadian kebakaran memerlukan sikap penanggulangan kebakaran dengan cepat. Tujuan penelitian untuk mengetahui hubungan pengetahuan mahasiswa tentang penggunaan Alat Pemadam Api Ringan (APAR) dengan sikap penanggulangan kebakaran di Laboratorium Kimia Unitri Malang. Desain penelitian menggunakan cross sectional. Sampel terdiri dari mahasiswa Teknik Kimia UNITRI Malang tahun angkatan 2019 sebanyak 53 responden yang diambil menggunakan simple random sampling. Pengumpulan data menggunakan kuesioner dan dianalisis dengan uji fisher-exact. Hasil didapatkan responden memiliki tingkat pengetahuan kategori baik (58,5\%) dan memiliki sikap kategori baik $(67,9 \%)$. Analisis uji fisher-exact didapatkan ada hubungan pengetahuan mahasiswa tentang penggunaan APAR dengan sikap dalam penanggulangan kebakaran. Diharapkan ada pelatihan penggunaan APAR secara berkesinambungan dan dilakukan sosialisasi yang berkelanjutan setelah pelatihan sehingga dapat mengetahui cara penanggulangan kebakaran.
\end{abstract}

Kata Kunci: APAR; kebakaran; pengetabuan; sikap

Cara mengutip: Sutriningsih,A., Choeron, R.C., Ndae, S.A. (2021 Pengetahuan Mahasiswa Tentang Penggunaan Alat Pemadam Api Ringan (APAR) Berhubungan Dengan Sikap Dalam Penanggulangan Kebakaran. Nursing News: Jurnal Ilmiah Keperawatan. Vol 5, No 2, 2021, hal 56-62. Retrieved from

https://publikasi.unitri.ac.id/index.php/fikes/article/view/2307 


\section{PENDAHULUAN}

Angka kebakaran di Indonesia masih cukup tinggi. Beberapa penyebabnya adalah listrik atau hubungan pendek arus listrik, kurang penataan ruang yang baik dan minim prasarana penanggulangan bencana kebakaran (BNPB, 2019). Salah satu upaya mengatasi kebakaran menggunakan APAR. Kebakaran merupakan kejadian yang tidak diinginkan karena menyebabkan penderitaan dan malapetaka akibat api yang membesar. Masalah kebakaran adalah kerugian material, korban, kecatatan fisik dan pengaruh psikologis yang dapat mengurangi kejiwaan korban (Azrini dkk, 2015). Masyarakat/ mahasiswa tidak bisa memadamkan kebakaran karena kurangnya pengetahuan dalam penanggulangan kebakaran menggunakan APAR.

Kebakaran dapat di cegah tetapi kejadiannya masih cukup tinggi sehingga penting pengetahuan dalam peanggulangannya terutama dalam penggunaan APAR (Fitriana dkk, 2017). Upaya penanggulangan kebakaran yaitu menyediakan APAR sehingga diharapkan siapa saja bisa menggunakannya apabila terjadi kebakaran. APAR digunakan memadamkan kebakaran kecil dan masih terkontrol atau belum membakar langit- langit. Upaya penanggulangan kebakaran terdiri dari perencanaan, pengorganisasian, penyediaan jalur evakuasi, penyediaan sarana dan fasilitas, pembinaan, dan latihan penanggulangan kebakaran untuk meningkatkan pengetahuan (Fitriana dkk, 2017).

Pengetahuan mahasiswa tentang penggunaan APAR sangat penting dimiliki apabila terjadi kebakaran dapat bertindak secara benar. Pengetahuan sebagai bentuk informasi membentuk sikap dan tindakan seseorang (Anderson \& Krathwohl, 2015). Sikap adalah reaksi terhadap stimulus yang terbentuk oleh informasi agar mampu menumbuhkan sikap positif. (Skinner, 2012).

Berdasarkan studi pendahuluan pada tanggal 13 Juli 2020 di Laboratorium Kimia Malang terdapat satu buah alat pemadam api ringan dengan wawancara 10 mahasiswa, diketahui sebanyak 8 orang tidak mengetahui manfaat APAR yang disimpan di lingkungan kampus dan tidak mengetahui cara penggunaannya, sedangkan sebanyak 2 orang mengetahui manfaat APAR untuk memedamkan kebakaran namun tidak mengetahui cara penggunaannya karena sama sekali tidak pernah memegang alat tersebut. Resiko kejadian kebakaran pada laboratorium 
kimia UNITRI Malang sangat tinggi karena kegiatan praktikum mahasiswa sering melakukan eksperimen atau penelitian menggunakan bahan kimia yang mudah terbakar, hal ini menyebabkan perlunya pengetahuan mahasiswa tentang penggunaan APAR. Bagi ilmu keperawatan hal ini berkaitan dengan mata kuliah Keselamatan dan Kesehatan Kerja. Kejadian kebakaran juga masuk dalam mata kuliah Keperawatan Bencana yaitu bencana yang diakibatkan oleh faktor non alam.

\section{METODE PENELITIAN}

Desain penelitian menggunakan korelasional untuk mencari hubungan pengetahuan mahasiswa tentang penggunaan apar dengan sikap dalam penanggulangan kebakaran. Pendekatan penelitian secara cross sectional yaitu pemberian kuesioner hanya sekali saja pada masing responden (Arikunto, 2015). Sampel dalam penelitian ini sebanyak 53 mahasiswa Teknik kimia UNITRI Malang tahun angkatan 2019, dengan kriteria kriteria inklusi dan kriteria ekslusi, dimana pengisian kuisioner secara online dengan menggunakan google form. Variabel bebas terdiri dari pengetahuan dan variabel terikat terdiri dari sikap. Variabel pengetahuan dan sikap diukur menggunakan kuesioner dan telah diuji validitas dan reliabilitas dengan hasil nilai alpha Cronbach $>0,63$. Selanjutnya data dianalisis secara univariate dan bivariate. Analisis univariate disajikan dalam table distribusi frekuensi, sedangkan analisis bivariate diuji Fisher Exact.

\section{HASIL}

Tabel 1 Karakteristik Responden berdasarkan Usia dan Jenis Kelamin

\begin{tabular}{llll}
\hline Karakteristik & & $\mathrm{f}$ & $(\%)$ \\
\hline Usia & $<20$ tahun & 17 & 32,1 \\
& $\begin{array}{l}21-30 \\
\text { tahun }\end{array}$ & 36 & 67,9 \\
& Laki-laki & 44 & 83,0 \\
Jenis & Perempuan & 9 & 17,0 \\
kelamin & & 53 & 100 \\
\hline Total & & & \\
\hline
\end{tabular}

Tabel 1 menunjukkan sebagian besar responden berusia 21-30 tahun sebanyak $67,9 \%$, dan hampir seluruh responden berjenis kelamin laki-laki sebanyak 83,0\%.

Tabel 2 Karakteristik Responden berdasarkan Pengetahuan dan Sikap

\begin{tabular}{lll}
\hline $\begin{array}{l}\text { Variabel } \\
\text { Pengetahuan }\end{array}$ & $\mathrm{f}$ & $\%$ \\
\hline Baik & 31 & 58,5 \\
Cukup & 11 & 20,8 \\
Kurang & 11 & 20,8 \\
\hline Variabel Sikap & $\mathrm{f}$ & $\%$ \\
\hline Baik & 36 & 67,9 \\
Cukup & 11 & 20,8 \\
Kurang & 6 & 11,3 \\
\hline Total & 53 & 100 \\
\hline
\end{tabular}

Tabel 2 menunjukkan sebagian besar responden memiliki tingkat pengetahuan tentang penggunaan APAR dengan 
kategori baik sebanyak 58,5\%. Dan memiliki sikap dalam penanggulangan kebakaran dengan kategori baik sebanyak $67,9 \%$.

Tabel 3 menunjukkan hasil uji Fisher-exact didapatkan $p=0,000$ sehingga $\mathrm{H}_{1}$ diterima, sehingga ada hubungan pengetahuan mahasiswa tentang penggunaan APAR dengan sikap dalam penanggulangan kebakaran di Laboratorium Kimia UNITRI Malang. Hasil tabulasi silang didapatkan bahwa sebagian besar responden memiliki pengetahuan tentang APAR dan sikap penanggulangan kebakaran pada kategori baik sebanyak $58,5 \%$.

Tabel 3. Hubungan pengetahuan tentang penggunaan APAR dengan sikap dalam penanggulangan kebakaran

\begin{tabular}{|c|c|c|c|c|c|c|c|c|}
\hline \multirow{3}{*}{ Variabel } & & \multicolumn{4}{|c|}{ Sikap } & \multirow{2}{*}{\multicolumn{2}{|c|}{ Total }} & \multirow{3}{*}{$\begin{array}{l}\text { Fisher exact } \\
\text { p-value }\end{array}$} \\
\hline & & \multicolumn{2}{|c|}{$\mathrm{K}+\mathrm{C}$} & \multicolumn{2}{|l|}{ B } & & & \\
\hline & & $\mathrm{F}$ & $\%$ & $\mathrm{~F}$ & $\%$ & $\mathrm{f}$ & $\%$ & \\
\hline \multirow{3}{*}{ Pengetahuan } & $\begin{array}{l}\text { Kurang } \\
+\end{array}$ & 17 & 32,1 & 5 & 9,4 & 22 & 41,5 & \multirow{4}{*}{0,000} \\
\hline & Cukup & & & & & & & \\
\hline & Baik & 0 & 0 & 31 & 58,5 & 31 & 58,5 & \\
\hline Total & & 17 & 32,1 & 36 & 67,9 & 53 & 100 & \\
\hline
\end{tabular}

\section{PEMBAHASAN}

Pengetahuan Mahasiswa tentang Penggunaan APAR Di Laboratorium Teknik Kimia UNITRI Malang

Hasil penelitian didapatkan tingkat pengetahuan tentang penggunaan APAR masuk kategori baik. Pada variabel pengetahuan terdapat dua indikator yaitu indikator pengertian dan indikator penanggulangan kebakaran menggunakan APAR. Berdasarkan data yang diperoleh dari kedua indikator tersebut maka didapatkan hasil yang paling dominan terdapat pada indikator pengertian, sedangkan hasil yang terendah terdapat pada indikator penanggulangan kebakaran. Hal ini didukung data dari Laboratorium Teknik Kimia bahwa sebelum melakukan praktikum mahasiswa di ajarkan tentang cara penggunaan APAR, mengarahkan APAR ke sumber api dan cara penanggulangan kebakaran, sehingga apabila terjadi kebakaran mahasiswa telah mengetahui cara penanganan kebakaran dan penggunaan APAR. Didukung oleh penelitian Margatama \& Umar (2019) menyatakan pengetahuan berbanding lurus dengan perilaku dalam penggunaan APAR. 
Pengetahuan dipengaruhi usia, informasi dan pengalaman. Karakteristik umum responden berusia 21-30 tahun. Semakin berkembang daya tangkap dan pola pikirnya, pengetahuan yang diperolehnya semakin membaik. Informasi diperoleh melalui pendidikan formal maupun non formal dapat memberikan pengaruh jangka pendek (immediate impact) sehingga menghasilkan perubahan atau peningkatan pengetahuan. Pengalaman untuk memperoleh kebenaran dan pengetahuan yang dilakukan secara berulang. Keseluruhan responden mahasiswa, artinya responden yang memiliki pendidikan yang tinggi akan mudah menerima informasi baru. Lingkungan yang memungkinkan timbulnya interaksi timbal balik direspon sebagai pengetahuan oleh setiap individu.

Pengetahuan dan informasi tidak dapat dikesampingkan dalam upaya mengidentifikasi tingkat pengetahuan seseorang. Apabila seseorang memiliki pendidikan yang tinggi dan memperoleh informasi yang banyak akan mempengaruhi sikap orang tersebut. Dalam penelitian ini mahasiswa sebagai responden diharuskan mengetahui tentang penggunaan APAR.
Sikap Mahasiswa dalam

Penanggulangan Kebakaran Di Laboratorium Kimia UNITRI Malang Hasil penelitian didapatkan sebagian besar responden memiliki sikap dalam kategori baik. Pada variabel sikap terdapat tiga indikator yaitu kognitif, afektif, dan konatif. Pada indikator konatif terdapat 17 orang dari 53 responden memiliki sikap dengan kategori kurang baik dalam penanggulangan kebakaran. Sedangkan untuk kategori kognitif dan afektif terdapat 11 orang dari 53 responden memiliki sikap dengan kategori kurang baik. Dari ketiga indikator tersebut maka didapatkan hasil yang paling dominan terdapat pada indikator konatif, sedangkan hasil yang terendah terdapat pada indikator kognitif dan afektif. Hal ini tampak di mahasiswa bahwa sebelum melakukan praktikum, mahasiswa teknik kimia angkatan 2019 di ajarkan cara penggunaan APAR, difasilitasi alat pemadam api ringan (APAR) Laboratorium Kimia. Adapun praktikum yang memicu kebakaran seperti asam asetat yang mudah terbakar dan tabung reaksi untuk destilasi, apabila suhunya tinggi tabung reaksi tersebut akan meledak. Didukung oleh penelititan Notoadmodjo (2014) menjelaskan bahwa sikap dalam penanggulangan kebakaran adalah kesiapan seseorang untuk 
melakukan penanggulangan kebakaran apabila terjadi.

Faktor yang mempengaruhi sikap mahasiswa dalam penanggulangan kebakaran yaitu faktor pengalaman pribadi dan lembaga pendidikan. Pengalaman menjadi dasar pembentukan sikap. Sikap mudah terbentuk apabila pengalaman pribadi tersebut terjadi dalam situasi yang melibatkan faktor emosional. Lembaga pendidikan sebagai upaya pembentukan moral yang mempengaruhi sikap (Azwar, 2012). Peran pengalaman pribadi dan lembaga pendidikan membentuk pengetahuan tidak dapat dikesampingkan untuk sikap dalam penanggulangan kebakaran dikarenakan pengetahuan menjadi salah satu faktor yang bisa mempengaruhi sikap dalam penanggulangan kebakaran. Seorang dengan pengetahuan tinggi akan bereaksi ketika lingkungan sekitar memberi stimulus atau terdapat ancaman pada daerah tersebut. Adapun faktor lain yang berhubungan dengan sikap yaitu informasi melalui media massa (Azwar, 2012).

Hubungan Pengetahuan Mahasiswa Tentang Penggunaan APAR dengan Sikap dalam Penanggulangan Kebakaran

Hasil penelitian didapatkan ada hubungan pengetahuan mahasiswa tentang penggunaan APAR dengan sikap dalam penanggulangan kebakaran di Laboratorium Kimia UNITRI Malang. Hal ini sesuai penelitian Anderson \& Krathwohl (2015) menyatakan pengetahuan penting untuk terbentuknya tindakan seseorang (over behavior). Perilaku yang dibentuk dari pengetahuan akan lebih lama dipahami.

Faktor yang mempengaruhi sikap mahasiswa tentang penggunaan APAR yaitu pengetahua dan sikap mahasiswa. Pengetahuan yang baik merupakan bentuk sikap pernyataan yang didasari emosi dan berfungsi sebagai pengalihan bentuk mekanisme pertahanan ego, munculnya sikap berasal dari adanya pengetahuan yang dimiliki seseorang (Azwar, 2012). Penelitian Azrini dkk (2015) menyatakan faktor yang mempengaruhi kemampuan penanggulangan kebakaran yaitu pengetahuan. Pengetahuan yang kurang menyebabkan seseorang tidak mengetahui cara penanganan kebakaran dan penggunaan APAR. Pengalaman pribadi juga mempengaruhi sikap karena menjadi dasar pembentukan sikap, pengalaman pribadi haruslah meninggalkan kesan yang kuat. Jadi peran pengetahuan dan pengalaman pribadi tidak dapat dikesampingkan untuk sikap dalam penanggulangan kebakaran dikarenakan 
pengetahuan menjadi salah satu faktor yang bisa mempengaruhi sikap dalam penanggulangan kebakaran.

\section{KESIMPULAN}

Sebagian besar mahasiswa memiliki pengetahuan tentang penggunaan APAR dengan kategori baik. Sebagian besar mahasiswa memiliki sikap dalam penanggulangan kebakaran dengan kategori baik. Ada hubungan pengetahuan mahasiswa tentang penggunaan APAR dengan sikap dalam penanggulangan kebakaran di UNITRI Malang.

\section{REFERENSI}

Anderson, L. W. \& D. R. Krathwohl. 2015. Kerangka Landasan Untuke Pembelajaran, Pengajaran, dan Asesmen Revisi Taksonomi Pendidikan Bloom. Terjemahan Agung Prihantoro. Yogyakarta: Pustaka Belajar

Arikunto, S. 2015. Prosedur Penelitian Suatu Pendekatan Praktek. Jakarta: PT. Rineka Cipta.

Azrini M., Denny H. M \& Widagdo H. 2015. Studi Tentang Perilaku Operator Dalam Kesiapsiagaan Penanggulangan Bahaya Kebakaran Di PT. X Suralaya. Jurnal Kesehatan Masyarakat (e-Journal) 3 (3). Universitas Diponegoro.

https://media.neliti.com/media/publ
ications/18682-ID-studi-tentang-

perilaku-operator-dalamkesiapsiagaan-penanggulanganbahaya-kebaka.pdf. Diakses pada tanggal 25 November 2019.

Azwar, S. 2012. Sikap Manusia: Teori dan Pengukurannya. Yogyakarta: Liberty.

BNPB. 2019. Serba Kejadian 2019. Jakarta: Badan Nasional Penanggulangan Bencana. https://bnpb.cloud/dibi/. Diakses pada tanggal 25 November 2019.

Fitriana L., Suroto \& Kurniawan B. 2017. Faktor-Faktor Yang Berhubungan Dengan Upaya Kesiapsiagaan Karyawan Bagian Produksi Dalam Menghadapi Bahaya Kebakaran Di Pt Sandang Asia Maju Abadi. Jurnal Kesehatan Masyarakat (e-Journal) 5 (3). Universitas Diponegoro. https://media.neliti.com/media/publ ications/163159-ID-faktor-faktoryang-berhubungan-dengan-up.pdf. Diakses pada tanggal 25 November 2019.

Margatama, W., \& Umar, A. F. (2019). Hubungan Pengetahuan dengan Perilaku Dalam Penggunaan APAR Pada Karyawan Di PT Adhi Persada Gedung Bekasi 2018. Jurnal Persada Husada Indonesia Volume 6 no 21, pp: 65-66.

Notoatmodjo. 2014. Konsep Ilmu Keperawatan. Jakarta : Salemba Medika. Skinner. 2012. Ilmu Pengetahuan dan Perilaku Manusia. Jakarta: Pustaka Pelajar 